\title{
The rhizome: A problematic metaphor for teaching and learning in a MOOC
}

\author{
Jenny Mackness \\ Independent Education Consultant and Researcher \\ Frances Bell \\ Itinerant Scholar \\ Mariana Funes \\ Chartered Research Psychologist
}

Deleuze and Guattari's principles of the rhizome were used to inform the design of a massive open online course (MOOC), Rhizomatic Learning: The Community is the Curriculum, which came to be known as Rhizo14. In a previous paper about learner experiences in this course our reported findings from a qualitative survey (which enabled anonymous responses) raised concerns about the ethics of using experimental pedagogies in designing MOOCs. In this paper, we continue this research and report learners' understandings of the rhizome as applied in Rhizo14, from what participants have told us in email interviews and from our own reflections on participation in the course. Our findings reveal that many participants could relate to and welcomed the anti-authoritarian, antihierarchical characteristics of the rhizome, but that knowledge and understanding of Deleuze and Guattari's conceptual principles of the rhizome was more difficult. Lack of engagement with theory and lack of appreciation of the incompleteness and complexities of the rhizome metaphor can result in negative consequences, such as imbalances in power relations and increased vulnerability for some learners.

This is the second in a series of three papers we are writing to report on our research into learning and teaching in the Rhizomatic Learning: The Community is the Curriculum massive open online course (Rhizo14), which ran between January 14 and February 25, 2014.

The design and delivery of this MOOC was informed by Deleuze and Guattari's (1980/2013) concept of the rhizome. We were participants and researchers in Rhizo14 and published our initial findings in Mackness and Bell (2015). Our key finding was that experimental pedagogies such as those based on the rhizome could lead to both light and dark experiences. This finding confirmed the excitement and motivation that an experimental pedagogy can generate, but also revealed more negative outcomes experienced by some participants.

Mindful of reviews of MOOC research which have suggested that there has not yet been enough research into pedagogy and learner experiences in MOOCs (Liyanagunawardena, Adams \& Williams, 2013; Yousef, Chatti, Schroeder, \& Jakobs, 2014; Yuan \& Powell, 2013), we continue our research with an exploration into the learners' experiences of using the rhizome as a conceptual framework for teaching and learning in a MOOC.

In this second paper we explore the strengths and weaknesses of the concept of the rhizome for teaching and learning as used by Rhizo14 participants. We seek answers to questions such as, "What were participants' understandings of the rhizome? How was the rhizome concept used in this context?" Like Massumi (1992, p. 8, cited in St. Pierre, 2004) we ask, "What new thoughts does the concept make it possible to think? And does it work?” We explore this last question in our conclusion to this paper.

\section{Rhizo14 - a course informed by the rhizome}

Rhizo14 is the hashtag by which the Rhizomatic Learning: The Community is the Curriculum MOOC came to be known. Rhizo14 was designed as a connectivist MOOC (known as a cMOOC). cMOOCs can take a variety of pedagogical approaches. Approaches to their design are still evolving (Bates, 2015) but all are based on four key principles: autonomy, diversity, interactivity, and openness (Downes, 2014). 
cMOOCs emphasise and promote connectivity, content creation by participants, open sharing and peerto-peer teaching and support, with no set curriculum, assessment, or formal teacher-student relationships (Bates, 2015).

Another key characteristic of cMOOCs is that the learning takes place across distributed social media sites rather than within an institutional platform (Bayne \& Ross, 2014; Haggard, 2013). This necessitates distributed open communication between self-motivated learners and results in "a self-organising network with many sub-components” (Bates, 2015, Chapter 5, Section 5.3.2.2).

Working across distributed platforms challenges assumptions about the nature of the curriculum, how knowledge is created, the role of the teacher, and the learning support that learners can expect (Cormier, 2008). Challenges to traditional ways of thinking about teaching and learning lie at the heart of rhizomatic learning and ultimately these challenges were the curriculum for the Rhizo14 MOOC.

Rhizo14 was convened by Dave Cormier and officially ran for 6 weeks, but continued unofficially, as a result of enthusiasm and interest of active participants, for another 6 weeks. The course attracted more than 500 participants, but as not all participants formally registered for the course, the exact number of participants who started the course is not known. As is the case with all courses of this type, the number of visibly engaging participants was much smaller by the end of the course.

The intention of the MOOC was to challenge the traditional notion of a course where the content is planned in advance. The course was therefore an experiment designed to explore "What happens when we approach a learning experience and we don't know what we are going to learn? Where each student can learn something a little bit different - together?” (Cormier, 2014a).

The title of the course suggests that Deleuze and Guattari's (1980/2013) concepts and the principles of the rhizome would be discussed, but there were no objectives for the course. Cormier (2014b) in his introduction to the course wrote that "You can have personal objectives. You can have group objectives. But I'm not creating objectives for anyone.” He also stated that he was "a nomad, not a knower” and that he was "hosting a party, not trying to tell you what or how to think" (Cormier, 2014b) and he urged participants to:

Try to forget everything you know about 'traditional education' and imagine that you are going to camp for 6 weeks.

Each week's discussion was based on a provocative statement or question, as follows:

- Week 1 - Cheating as Learning (January 14-21)

- Week 2 - Enforcing Independence (January 21-28)

- $\quad$ Week 3 - Embracing Uncertainty (January 28 - February 4)

- Week 4 - Is Books Making Us Stupid? (February 4-11)

- Week 5 - Community As Curriculum (February 11-18)

- $\quad$ Week 6 - Planned Obsolescence (February 18-?)

These weekly topics, each introduced by a short video in the Peer 2 Peer University course web page (Cormier, 2014a), were the content the course provided. The lack of objectives led to a planned ambiguity about what would or could become topics. The intention was that the community would be the curriculum, rather than any prescribed content being offered.

In Week 2 a storm blew up in the Facebook group for the course. We sum up this incident below because it had a significant impact on the course dynamics.

Two participants objected to a blog post by a third who had suggested that engagement with theory might be necessary to understand rhizomatic learning. What could have been framed as simply two different kinds of personal objectives (to learn more about the theory and to ignore the theory) became instead a site of contention. The situation was resolved by all three parties leaving the course, and the discussion of theory being seen as problematic from that point on. We will show how this had implications for participants' understanding of the rhizome concept and its relationship to teaching and learning. 


\section{Metaphors in teaching and learning}

Metaphors have long been used in education as a means of opening the way for new understanding (Northcote \& Fetherston, 2006). A metaphor invites us to see similarities and can create powerful insights. Lakoff and Johnson (2008, p. 131) write: "New metaphors have the power to create a new reality”, because as Lakoff (1992) explained, metaphor is not just a matter of language, but of abstract thought and reasoning. The use of metaphor involves mapping across different conceptual domains within our conceptual system. We understand one domain of experience in terms of another and mapping a set of correspondences from one to the other (Lakoff, 1992). In our context for this paper, an example of this mapping might be that from the rhizome to teaching and learning.

This distinction made by Lakoff (1992) between understanding metaphor "as a novel or poetic linguistic expression” (p. 1) and understanding metaphor as conceptual cross-domain mapping, relates closely to Deleuze and Guattari's (1980/2013) work on the rhizome. For Deleuze and Guattari, the rhizome is a concept that challenges authoritarian and hierarchical ways of thinking. Despite their extensive use of metaphor in their book A Thousand Plateaus, they eschewed the word metaphor in favour of metamorphosis, writing (1975/1986, p. 22):

Metamorphosis is the contrary to metaphor. ... It is no longer a question of a resemblance ... Instead, it is now a question of a becoming ...

Deleuze and Guattari (1980/2013) were interested in the conceptual changes that could result from rhizomatic thinking. They believed that viewing the rhizome as a metaphor (in the sense of a linguistic expression) would imbue in the rhizome an unwelcome power and lead to over-representation and reification. We will see in the next section that these characteristics are contrary to the principles of rhizomatic thinking as postulated by these authors.

Elizabeth St. Pierre (2004) thinks it is possible to over-think what Deleuze might mean and suggests that we:

give up worrying about what Deleuze might have intended and use him in [our] own work 'to free life from where it's trapped, to trace lines of flight' (Deleuze, 1990/1995, p. 141) into a different way of being in the world. (p. 284)

Likewise, for the purposes of this paper we will not worry unduly about whether the rhizome is metamorphosis or literary metaphor. We will consider the rhizome as a conceptual (about thinking and reasoning) metaphor and explore the extent to which it works. As such, when we refer to metaphor in what follows this will be our definition. We understand this more widely than the work of cognitive linguists (e.g., Lakoff \& Johnson, 2008) explored earlier, as in their definition metaphorical structuring is unconscious rather than purposeful (Lakoff \& Johnson, 1999).

If metaphors such as the rhizome can be used to change learners' conceptual frameworks and encourage people to think outside the box, they require skilled use and need to be treated with caution. This is particularly the case with complex metaphors, such as the rhizome, if they are being used to elicit subtle and nuanced insights into complex realities. Lakoff (1992) points out that metaphors are asymmetric and partial and Morgan (1997) writes of metaphors, "in creating ways of seeing they tend to create ways of not seeing” (p. 348). Metaphors shape the way we see and the way we act, they enact a particular view and can be "self-fulfilling prophecies" (Lakoff \& Johnson, 2008, p. 132). Any cross-contextual mapping highlights a set of features whilst backgrounding others. This is the case in all metaphors, including the rhizome. As Lakoff (1992) noted with reference to Reddy's (1979) definition and description of the conduit metaphor:

Reddy showed ... that metaphor is a major and indispensable part of our ordinary, conventional way of conceptualizing the world, and ... our everyday behavior reflects our metaphorical understanding of experience. (p. 2)

If we think teaching is a rhizome certain actions ensue. If we think teaching is a conduit (Reddy, 1979), then different potential actions are brought to the fore. 
Having established that metaphors need to be treated with care and that for the purposes of this paper when we discuss metaphor we are referring to conceptual rather than literary metaphor, we will now outline some of Deleuze and Guattari's (1980/2013) principles of rhizomatic thinking and will report on how participants in Rhizo14 understood the rhizome.

\section{The rhizome}

In botanical terms a rhizome is a subterranean stem of a plant, a creeping root stalk, which spreads laterally in multiple directions and surfaces to produce a clone of the original plant in an unexpected location. Some rhizomes, such as ground elder, are considered weeds which gardeners find very difficult to control. Other rhizomes, such as lilies of the valley, with their beautiful scented flowers, are more welcome. The botanical rhizome has both positive and negative interpretations, and these may vary by location; in the old saying a weed is a plant in the wrong place.

The rhizome metaphor has been used to describe fast-growing concepts or communities, such as the Internet, where the mechanism of growth is hidden (Buchanan, 2007), just as the growth of the rhizome is hidden.

The concept of the rhizome has also been used by Deleuze and Guattari (1980/2013) to explore ways of thinking that challenge hierarchies and deprivilege centres of authority. For them the rhizome concept related not only to its botanical equivalent but also to burrows, viruses and animals such as rats. Deleuze and Guattari thought of the rhizome in terms of six principles: connection, heterogeneity, multiplicity, asignifying rupture, cartography, and decalcomania (see Figure 1). This figure quotes from Deleuze and Guattari's book A Thousand Plateaus (1980/2013). Figure 2 suggests how their six principles of the rhizome might inform teaching and learning. 


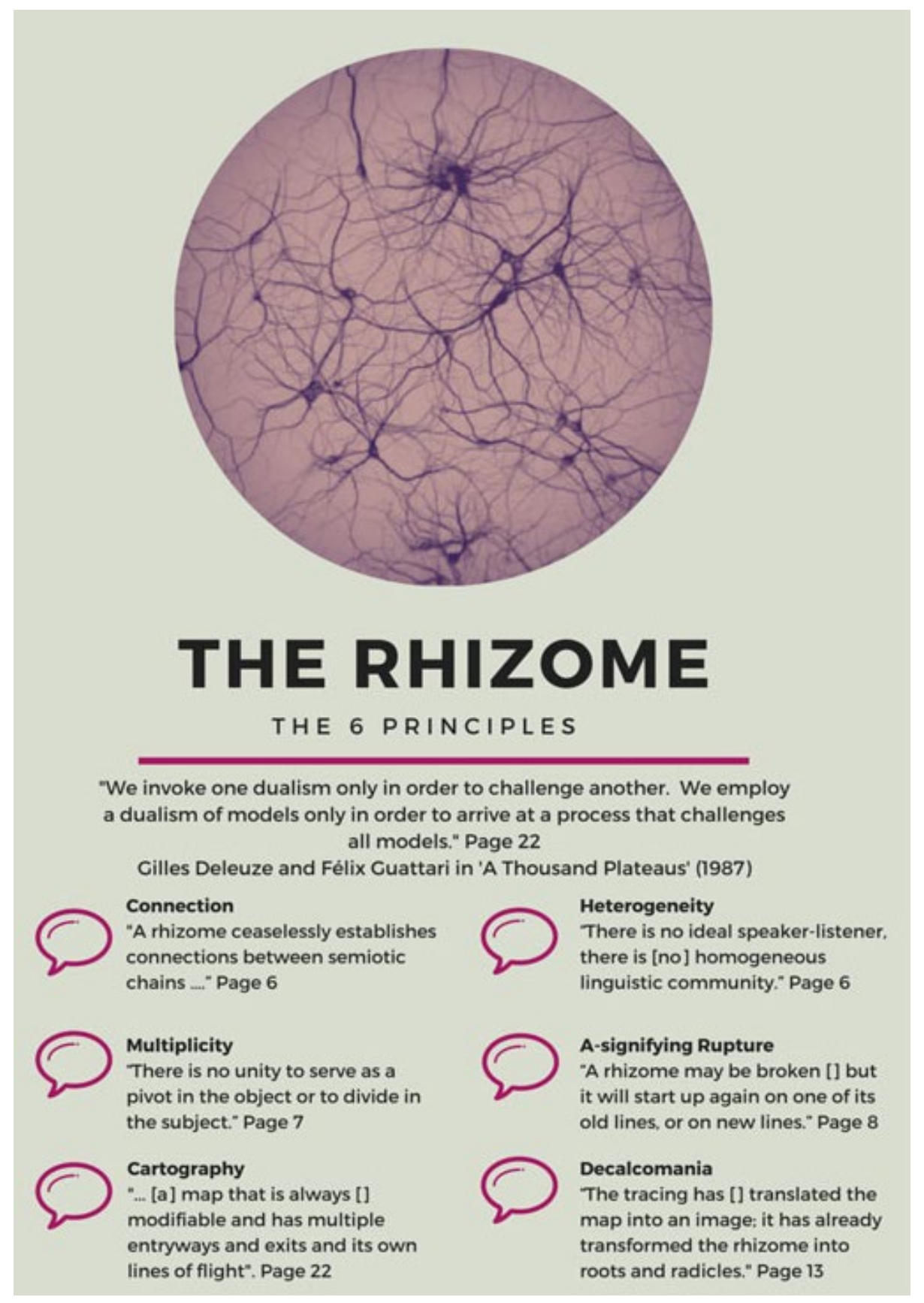

Figure 1. Principles of the rhizome from Deleuze and Guattari (1980/2013) 


\title{
RELEVANCE TO TEACHING AND LEARNING CONNECTION/HETEROGENEITY

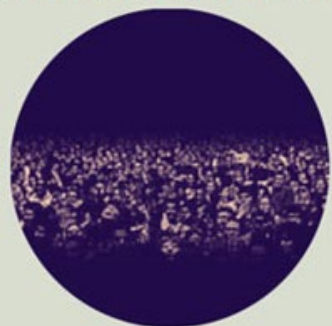 \\ Encourage ceaseless connection and diversity in people, ideas and resources. The system has no beginning or end, and can be entered at any point.
}

\section{MULTIPLICITY/A-SIGNIFYING RUPTURE}

\author{
Design is a-centred and anti- \\ hierarchical. It allows for break \\ away groups or individuals to re- \\ organise in locations of their \\ choice.
}

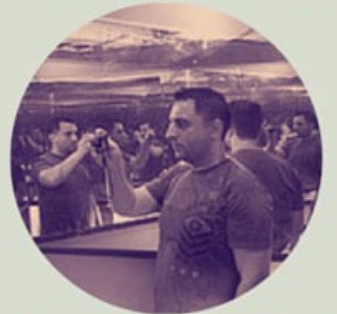

\section{CARTOGRAPHY/DECALCOMANIA}

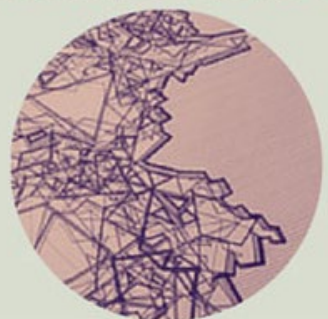

Learners create and follow selfselected, individual pathways and embrace uncertainty without attempts to predict learning outcomes.

Figure 2. The relevance of the rhizome to teaching and learning (Funes, 2015.)

In addition to these six principles, Deleuze and Guattari (1980/2013) introduce and discuss a number of other concepts, which are inextricably linked to the six principles of the rhizome and relevant to the use of the rhizome concept in bringing a new perspective on teaching and learning. Amongst the most significant of these concepts for teaching and learning that challenge traditional ways of thinking, are lines of flight and the nomad.

\section{Lines of flight and the nomad}

Deleuze and Guattari (1980/2013) worked with schizophrenic patients and others with complex mental problems. The traditional therapeutic approach had been to try and solve a problem through analysis. Deleuze and Guattari encouraged their patients to take lines of flight. They wanted them to eschew the constraints of traditional modes of thinking, leave the problem behind, and take their thinking in a different direction (Gale \& Bowstead, 2013). This was not flying or running away; rather it was running off, as a watercourse will run off from its main source (Hamon, 2011). Lines of flight are a means of evading dominator systems of thought, a means of breaking down existing connections and power relations (Winslade, 2009) and creating new ones; a means of flowing, leaking, disappearing into the distance - reminiscent of the vanishing point that we see in some paintings and photographs (Massumi, 2013). A line of flight escapes territorialisation and, through deterritorialisation (a sudden swerve or rupture creating new lines of segmentarity) metamorphoses into something new. This does not need to be a big shift; it can be subtle. Lines of flight are always part of the rhizome, but are not without risk, and can lead to destruction or to reterritorialisation. They are not a guarantee of a new way of thinking but, significant for teaching and learning, lines of flight enable us to think otherwise and resist codes and powers (Deleuze, 1988, cited in Avalos \& Winslade, 2010). 
Deleuze and Guattari's (1980/2013) interest in the nomad was not in people, but with nomadic thought. Nomad thought is practically impossible to define, it has no method, it has neither beginning nor end, but is always in the middle (Holland, 2013, p. 46). Nomads are always deterritorialising. Deleuze and Guattari (1980/2013) wrote "the nomad can be called the Deterritorialized par excellence” (p. 444). Nomads are adaptive and constantly evolving, they go with the flow, resist authority and control, and are “indifferent to boundaries laid down by the State apparatus” (Leung, 2010). Wray (1998) writes:

The rhizome and the nomad are inseparable in the sense that the rhizome is the path that the nomad follows.

Lines of flight, nomadic thought, and the principles of the rhizome are therefore useful concepts for encouraging teachers and learners to break free from traditional ways of thinking and working.

\section{Understanding the rhizome - from Rhizo14 course participant perspectives}

\section{Collecting the data}

Rhizo14 participants were surveyed about their understanding of the relationship between the rhizome and teaching and learning. A total of 47 responses were received (out of an estimated 500) and over 30,000 words of data (Mackness \& Bell, 2015). Two significant aspects of our research methodology are:

- We shared our research progress on our blogs and, in particular, before starting our research we discussed our ethical approach with Rhizo14 participants (Bell, 2014).

- $\quad$ Our survey offered the opportunity for participants to make anonymous responses. Ultimately this enabled us to report on the hidden MOOC experience.

The methodology and ethics of this data collection, and subsequent findings, have been reported in detail in Mackness and Bell (2015).

Of the 47 survey respondents 35 also volunteered to take part in a further email interview. This interview was designed to elicit information about participants' understanding of the rhizome metaphor and to follow up on their survey responses with individual questions. (We chose the word metaphor, as opposed to concept, because that was our understanding (and that generally of Rhizo14 participants) at the time of writing the interview questions.) The interview questions were framed from statements made by participants in response to the first survey. Twenty-five participants responded to the email interview. Participants selected the statements they wanted to respond to. Fourteen participants did not respond to any of the six statements, but instead expanded on their individual question. Some of these responses were in depth and provided an additional 15,000 words of very rich data.

\section{Rhizo14 participants' understanding the rhizome}

The rhizome was thought by interview respondents to be useful for exploring new ways of thinking about education, but incomplete. For most it was understood in terms of its botanical equivalent, but one respondent described it as "the new wineskin for the new wine" and wrote:

Now, having said that, I do not think the rhizome is the complete new wineskin. I think complexity, for instance, is a larger, more inclusive framework for rethinking education and pretty much everything else. But complexity is a rather abstract term that mostly confuses people. A rhizome is tangible, and therein lies its power as a metaphor: it compares something you can touch to something more abstract. For me, that is powerful.

Recognition of the rhizome as tangible was also acknowledged by anthropologists Douglas-Jones and Sariola (2009) who physically dug up an iris to support them in their auto-ethnographic process of learning to understand Deleuze and Guattari. 
The rhizome was also thought to be useful as an explicit metaphor for explaining how knowledge is created through social learning on the Internet, "The best social learning leads to the co-creation of knowledge" (interview respondent), particularly across distributed platforms in environments where learning can be complex, chaotic, unpredictable, exploratory, creative and playful. Like Buchanan, some respondents noted links between rhizomatic learning, community learning and networked learning. "There are of course excellent grounds for thinking that the Internet meets some if not all of the basic criteria of the rhizome, which Deleuze and Guattari list” (Buchanan, 2007, p. 9). Despite noting these links, respondents seemed unclear about whether a rhizome suggests a network or a community and whether and how it relates to connectivism:

Network and community. Two tricky words to compare/contrast. Not the same thing, though. Both organic. Ok. Community more affective. Network more rational and with an intent.

I see the two (rhizomatic learning and connectivism) as complementary - or perhaps "supplementary" would be the more correct term, because the two alone do not form a complete picture of networked learning.

I think it has significantly enhanced "my" understanding of teaching and learning. It represents a significant deviation from traditional models of education and has perhaps a stronger emphasis than Connectivism on treating the community as curriculum while at the same time promoting a higher sense of "self" in relation to community.

One respondent who described herself as never fully arriving or leaving the course wrote of connecting more to the metaphor as a learner than a teacher:

It probably relates more to my experience as a learner than as a teacher. I think we can intentionally create learning experiences for others that resemble this metaphor, but the more we attempt to design, the more we are contradicting ourselves.

This echoes Deleuze and Guattari's (1980/2013) concerns about over-representation and reification of metaphor that we discussed in the Metaphors in teaching and learning section of this paper.

Another respondent wrote, echoing Morgan’s (1997) use of multiple metaphors:

I still don't know what rhizomatic learning is. I've enjoyed (am enjoying) \#rhizo14 because of the people I have met (am meeting), but I think that it will need a lot more fleshing out before I can decide whether it is useful. I doubt if any one metaphor will ever be sufficient for learning, though.

Rhizomatic teaching was thought by some to challenge the status quo and power of the teacher, and like Bayne (2004) some thought that the teacher's job in rhizomatic teaching is to smooth striated spaces. A respondent wrote:

I think the rhizome metaphor does have a big impact on the role of the teacher because it emphasises more self directed learning processes, and more movement through uncertainty, complexity and ambiguity, and less validating a 'correct' answer by the teacher.

One respondent noted the contradiction of discussing rhizomatic teaching in a course where there was no curriculum:

Does the rhizome even allow for the existence of the word 'teacher' or even 'teach'? Is there only room for 'learn'? Maybe ... tough for a teacher to be utterly obsolete, huh?

A participant who valued the rhizome metaphor still sought intentional design at some level:

... even though I believe in rhizomes as a metaphor for learning, it's harder to connect it back to an intentionality around teaching and/or designing instruction ... 
Only one respondent mentioned the question of whether the rhizome is a metaphor for teaching and learning. Deleuze and Guattari (1980/2013) were emphatic in their animosity towards metaphor as resemblance, as we discussed earlier. One respondent stated that the rhizome is not a model or a theory; others explained it in terms of a lens, a stimulus, or a story. None of the respondents referred to it as a concept, which is how Deleuze and Guattari explained it, but then few respondents were familiar with Deleuze and Guattari’s work, and this was not generally seen as problematic:

I have not read the Thousand Plateaus. I will some day. I am very curious to do so, as a matter of fact. Just haven't yet mustered up the courage to tackle such a difficult text. Not having read it did not hinder my having a dense experience in rhizo14, though.

Some respondents were explicitly opposed to reading and discussing Deleuze and Guattari's work. "I was so hacked off by academic posturing around D\&G on Rhizo14 I've set my face against them." Others recognised the possibility of territorialising and thereby limiting the experience of rhizomatic learning.

For one respondent, who is familiar with Deleuze and Guattari’s work, "D\&G are poetic and beautiful”.

D\&G's poetry enhances the way I think and talk about education - and they added to \#rhizo14 - but you could enjoy \#rhizo14 without any great engagement with D\&G.

Ultimately for most respondents the value of the Rhizo14 experience lay in "the spirit of exploration, openness, experimentation, of trying new things" (interview respondent), rather than any engagement with Deleuze and Guattari's principles of the rhizome.

\section{The tragic paradox of the rhizome metaphor}

The rhizome is a complex concept, a multiplicity of principles and aspects. Rhizo14 was an attempt to put some of these principles into practice and in doing this it answered Massumi's question (1992, p. 8), which we posed at the beginning of this paper: "What new thoughts does it make possible to think?" Rhizo14 was designed to be a-centred and have minimum content and facilitation. Participants were encouraged to start wherever they wished, to make multiple connections between each other and with a diversity of participant generated and shared resources, to create their own personal learning maps and content, to engage in multiple different modes of activity, in multiple spaces, and to manage their own learning. A culture of play and fun emerged; many artefacts incorporating poetry, music, personal writings, photography, and art works were produced. A-signifying rupture and lines of flight, if not lines of fantasy, and nomadic behaviours were in evidence.

We have found from our continuing research that in Rhizo14, despite the course bearing the title Rhizomatic Learning: The Community is the Curriculum, there was limited willingness to discuss the complexity of the conceptual metaphor and how Deleuze, Guattari, and others had used the concept in different contexts. One interview respondent commented: "D\&G were not central to the experience at all in my view” and another commented:

I haven't read D\&G myself. I find the post-modern philosophical literature almost impossible to read. They keep inventing new words and define those words with even more new words. Even define words within itself. E.g. the not-being of being is as the unknowing of the knowing of the not ... It doesn’t mean anything to me.

The difficulties of reading and writing about the rhizome as a metaphor for thinking, and teaching and learning, such that the writing models the principles expounded by Deleuze and Guattari, and can yet be understood, has challenged a number of authors, including us. As St Pierre (1997) wrote:

Any writing space, any form of writing, becomes standardized and normalized and constrains content. (p. 375) 
Similar concerns were expressed by Douglas-Jones and Sariola (2009):

We are recognizing the academy's need to communicate ideas in writing, in a linear format. Even if methodologically and theoretically we become more rhizomatic, the imparting of knowledge currently requires some arborescence. (p. 2)

Like St. Pierre and Douglas-Jones and Sariola, we are also acutely aware of the arboreal constraints under which we are working and the pressure to produce a linear text which is ordered and coherent (Honan \& Sellers, 2006) and we accept that “attempts to synthesize are never finished” (Clarke \& Parsons, 2013, p. 35).

Perhaps the difficulties that many have with reading and writing about Deleuze and Guattari's work is the cause of the tragic paradox of the rhizome noted by Gregoriou (2004, p. 240):

The tragic paradox is that the rhizome has found a hospitable niche in pedagogical discourse only as a metaphor for de-centered and non-hierarchical systems of organization.

And Douglas-Jones and Sariola (2009, p. 29) have noted, "The conceptual rhizome does not map on to a botanical definition.”

One interview respondent also recognised this paradox:

I have a feeling that this metaphor needs to be connected more to pedagogical issues arising from educational research.

These pedagogical issues are those that the rhizome as a literal metaphor, without being grounded in the theoretical conceptual framework that originated it, cannot cover. Our data has shown that there was little agreement on what the rhizome means for teaching and learning; unpacking this would have required some co-definition and agreement by Rhizo14 participants, and early in the course discussion of theory was seen as unnecessary. Metaphors are always incomplete, and if we take the approaches to these of Lakoff (1992) and Lakoff and Johnson (1999) (which in our view is closer to how Deleuze and Guattari foresaw the rhizome) metaphors are often unconscious and embodied in experience. The rhizome is no exception. This incompleteness of the rhizome metaphor is emphasised when it is applied in contexts for which it was not intended, such as a course. This can result in over-representation of the metaphor's botanical equivalent and under-representation of other aspects of teaching and learning, such as "the ethical implications of pedagogical experimentation, interrelated processes of community and curriculum formation, the role of the MOOC convener, and learner experiences within MOOC communities”, which were highlighted by Mackness and Bell (2015, p. 25) as needing further research.

Deleuze and Guattari (1980/2013) identify further potential difficulties for learners in relation to the rhizome when they describe hierarchical thinking as being confined to a striated space and lines of flight as moving into smooth spaces. Smooth space is open space, whilst striated space is bordered. Movement within smooth space is free and nomadic. Movement in striated space is fixed along predetermined paths. In smooth space the movement is more important than the arrival. In striated space, the opposite is the case (Bayne, 2004). In Rhizo14 participants were encouraged to take lines of flight and occupy smooth space; to become nomadic learners. But as Deleuze and Guattari have pointed out, smooth space is not always trouble free. Movement in smooth space is unpredictable and uncertain with no end in sight. "Voyaging smoothly is a becoming, and a difficult, uncertain becoming at that" (Deleuze \& Guattari, 1980/2013, p. 482).

The smooth space of Rhizo14 was associated with some tension between participants who, in the absence of any significant course structure or guidelines, as reported above, wished to learn and connect in different ways. Some wanted to study Deleuze and Guattari and know more about the rhizome; others did not. The course embraced this disruption, uncertainty, and chaos as a necessary component of learning in an age of abundance and massive open online learning environments (Cormier, 2013), but in so doing did it increase the vulnerability of some participants as learners as suggested by Gale (2010)? Our evidence suggests that it did as we can see from the following quotes from three respondents: 
I think we do need to notice that a new sort of resilience needs to be nurtured.

You start to: “... become a little braver, actually make the leap from thinking about experimenting to actually doing it, no longer (as) afraid of being challenged or criticized, but become open to it ..."

What happens if I let go and cannot get back to myself?

The third quote in particular points to the challenges to identity and becoming that rhizomatic learning might present.

Tensions can also arise in relation to the rhizome principle of heterogeneity. The heterogeneity of people and ideas in a community that was also a course, such as Rhizo14, could result in uneven distribution of power with some individuals leveraging this power differential (de Freitas, 2012). This assertion would require further research to substantiate fully.

Yet this tension was noted by a respondent who wrote:

... questions about power and hierarchy rear their heads, even in environments which (or with individuals who) work explicitly to eliminate or ignore these features. Rather than ignore or deny these aspects, my personal preference has been to constructively acknowledge them and understand (and evaluate, perhaps) leadership not in terms of the relative or absolute power or controlling capacity of an individual or institution, but in terms of the degrees of facilitation and care and personal and collective/network growth as outcomes.

We can say that one consequence of freedom in choice about what we learn, is to participate unknowingly in the oppressive relations of power in education if we take too limited a focus.

For some Rhizo14 participants the course was experienced as chaos, as exemplified by this comment from a respondent:

It conveys an idea of messiness, chaos, learning being everywhere and growing in every direction.

But Deleuze and Guattari were opposed to chaos (Drummond, 2005). They intended the concept of the rhizome as a challenge to hierarchical thinking. They were interested in nomadic thought. As Gregoriou (2004,) noted, “The goal is not to represent the rhizome but to implant it in thought" (p. 240), and as Drummond (2005) noted, "The rhizome is not primarily an assemblage of resistance to the orthodox or status quo ... the tree is a necessary condition for the rhizome” (p. 259).

Lack of recognition of the necessary condition of the tree was perhaps the most significant element of the paradox of the rhizome evident in the Rhizo14 MOOC.

\section{The tree and the root - arboreal and rhizomatic thinking}

The concept of the rhizome has been applied successfully by learners and teachers within education (St. Pierre, 2004), but Deleuze and Guattari (1980/2013) did not place in opposition the root (rhizomatic thinking) and the tree (arboreal thinking), nor lines of flight and territorialisation, nor smooth and striated space. To do so would be to create a dogmatic image of thought (Drummond, 2005).

We are aware that a critique of the rhizome as a metaphor for teaching and learning could be viewed as a retreat into arboreal thinking, but like Drummond (2005), we do not believe that any research method can be intrinsically rhizomatic. We also believe that if the rhizome is going to be used as a stimulus for change, then superficial treatment and understanding of the concept is potentially damaging for learners' becoming. 
Deleuze and Guattari's (1980/2013) rhizome is a way of understanding the philosophy of becoming which takes learners into uncertain, unstable, and disruptive spaces (Gale, 2010). We have found that not only does the rhizome speak intimately to us, but also we can speak back more publicly to the theory, as recommended by Bennett and Oliver (2011). If the rhizome is to be used as a concept, metaphor, story, or lens for teaching and learning in massive open online learning environments, then we need to consider how it might be incomplete.

The rhizome metaphor does not call for the tree to be opposed to the root. Each is a necessary condition for the other (Drummond, 2005). There is need for both arboreal and rhizomatic thinking. The structure and support of the tree can and should work with the autonomy, freedom, motivation, lines of flight, and intensity of learning experience (Munday, 2012) that can be offered by the rhizome.

\section{Conclusion: Does it work?}

At the beginning of this paper we asked whether the rhizome works as a metaphor for teaching and learning in a MOOC.

We have shown both here and in our previous paper (Mackness \& Bell, 2015) that many of Deleuze and Guattari's (1980/2013) principles of the rhizome can be applied to teaching and learning in a MOOC. From the data we have collected and reported on both in our first paper (Mackness \& Bell, 2015) and in this paper, we can say that using the rhizome as a metaphor for teaching, learning, and course design requires knowledge and understanding of the theoretical principles outlined by Deleuze and Guattari (rhizome as a concept) and of the potential limitations of the metaphor for application to teaching and learning.

We recognise that the rhizome can successfully challenge traditional authoritarian, hierarchical approaches to teaching and learning, freeing learners to follow their own learning paths and determine their own learning objectives. However, as Deleuze and Guattari (1980/2013) pointed out, smooth space, the space of the rhizome, is a difficult space for learners' becoming, and as Gale (2010) noted, it increases the vulnerability of learners. As such, an ethical approach would be one that ensures that this vulnerability is acknowledged and that the consequences for learners' identity and becoming of adopting rhizomatic principles for course design are carefully thought through. Use of the rhizome metaphor for designing teaching and learning experiences necessitates consideration of distribution of power in smooth space and the fragility of the will to learn (Barnett, 2007). We suggest that this is more likely to be successful if we remember that Deleuze and Guattari (1980/2013) did not oppose the root and the tree and that they were opposed to chaos, as we explored in an earlier section.

This has implications for how curriculum is conceived in a MOOC design based on rhizomatic principles and how learners are supported in engaging with the curriculum. The full title of the Rhizo14 MOOC was Rhizomatic Learning: The Community is the Curriculum. In our third and final paper about learning in Rhizo14, we will explore further the formation and operationalisation of curriculum and will examine what the community is the curriculum means for teachers and learners.

\section{References}

Avalos, B. M., \& Winslade, J. (2010). Education as a “ line of flight ”. Explorations: An E-Journal of Narrative Practice, 1, 70-77. Retrieved from http://www.dulwichcentre.com.au/explorations-2010-1mariel-avalos-john-winslade.pdf

Barnett, R. (2007). A will to learn: Being a student in an age of uncertainty. Berkshire: Open University Press.

Bates, A. W. (Tony). (2015). MOOCs. Teaching in a digital age: Guidelines for designing teaching and learning (pp. 149-186). Retrieved from http://opentextbc.ca/teachinginadigitalage/chapter/section-7-4-design-models-for-moocs/

Bayne, S. (2004). Smoothness and striation in digital learning spaces. E-Learning and Digital Spaces, 1(2), 302-316. doi: 10.2304/elea.2004.1.2.6 
Bayne, S., \& Ross, J. (2014). The pedagogy of the massive open online course (MOOC): The UK view. York: Higher Education Academy. Retrieved from https://www.heacademy.ac.uk/resources/detail/elt/the_pedagogy_of_the_MOOC_UK_view

Bell, F. (2014). Rhizo14 research. Retrieved from https://francesbell.wordpress.com/research/rhizo14research/

Bennett, S., \& Oliver, M. (2011). Talking back to theory: The missed opportunities in learning technology research. Research in Learning Technology, 19(3), 179-189. doi:10.3402/rlt.v19i3.17108

Buchanan, I. (2007). Deleuze and the Internet. Australian Humanities Review, 43. Retrieved from http://www.australianhumanitiesreview.org/archive/Issue-December-2007/Buchanan.html

Clarke, B., \& Parsons, J. (2013). Becoming rhizome researchers. Reconceptualizing Educational Research, 4, 35-43. doi:10.7577/rerm.685

Cormier, D. (2008, June 3). Rhizomatic education: Community as curriculum. Innovate: Journal of Online Education, 4(5). Retrieved from http://davecormier.com/edblog/2008/06/03/rhizomaticeducation-community-as-curriculum

Cormier, D. (2013, December 27). Rhizomatic learning - An open course \#rhizo14 [Blog post]. Dave's Educational Blog. Retrieved from http://davecormier.com/edblog/2013/12/27/rhizomatic-learning-anopen-course-rhizo14/

Cormier, D. (2014a). Rhizomatic learning - The community is the curriculum. P2PU. Retrieved from https://courses.p2pu.org/en/courses/882/rhizomatic-learning-the-community-is-the-curriculum/

Cormier, D. (2014b, January 12). Your unguided tour of Rhizo14 [Blog post]. Dave's Educational Blog. Retrieved from http://davecormier.com/edblog/2014/01/12/your-unguided-tour-of-rhizo14/

De Freitas, E. (2012). The classroom as rhizome: New strategies for diagramming knotted interactions. Qualitative Inquiry, 18(7), 557-570. doi:10.1177/1077800412450155

Deleuze, G., \& Guattari, F. (1986). Kafka: Toward a minor literature. (D. Polan, Trans.). Theory and history of literature (vol. 30). Minneapolis: University of Minnesota Press. (Original work published in 1975)

Deleuze, G., \& Guattari, F. (2013). A thousand plateaus: Capitalism and schizophrenia. (B. Massumi, Trans.). Minneapolis: University of Minnesota Press. (Original work published in 1980)

Douglas-Jones, R. C., \& Sariola, S. (2009). Rhizome yourself: Experiencing Deleuze and Guattari from theory to practice. Rhizomes, 19. Retrieved from http://www.rhizomes.net/issue19/sariola.html

Downes, S. (2014, March 10). The MOOC of One. Keynote presentation at INTED 2014, 8th International Technology, Education and Development Conference, Valencia. Retrieved from http://www.downes.ca/presentation/336

Drummond, J. S. (2005). The rhizome and the tree: A response to Holmes and Gastaldo. Nursing Philosophy: An International Journal for Healthcare Professionals, 6(4), 255-66. doi:10.1111/j.1466769X.2005.00219.x

Funes, M. (2015, May 27). Principles of the rhizome - just a graphic [Blog post]. Double Mirror. Retrieved from http://mdvfunes.com/2015/05/27/principles-of-the-rhizome-just-a-graphic/

Gale, K. (2010). An inquiry in to the ethical nature of a Deleuzian creative educational practice. Qualitative Inquiry, 16(5), 303-309. doi:10.1177/1077800409358869

Gale, K., \& Bowstead, H. (2013). Deleuze and collaborative writing as method of inquiry. Journal of Learning Development in Higher Education, 6, 1-15. Retrieved from http://www.aldinhe.ac.uk/ojs/index.php?journal=jldhe\&page=article\&op=view\&path\%5B\%5D=222

Gregoriou, Z. (2004). Commencing the rhizome: Towards a minor philosophy of education. Educational Philosophy and Theory, 36(3), 233-251. doi:10.1111/j.1469-5812.2004.00065.x

Haggard, S. (2013). The maturing of the MOOC: Literature review of massive open online courses and other forms of online distance learning. London: Department for Business, Innovation and Skills. Retrieved from https://www.gov.uk/government/publications/ massive-open-online-courses-and-online-distance-learning-review

Hamon, K. (2011, November 30). \#change11 The Practical Rhizome: Heterogeneity 2 [Blog post]. Communications \& Society. Retrieved from http://idst-2215.blogspot.co.uk/2011/11/change11practical-rhizome_30.html

Holland, E. W. (2013). Deleuze and Guattari's A Thousand Plateaus. London: Bloomsbury.

Honan, E., \& Sellers, M. (2006). So how does it work? - Rhizomatic methodologies. Paper presented at the AARE Annual Conference, Adelaide. Retrieved from http://www.aare.edu.au/publicationsdatabase.php/5086/so-how-does-it-work-rhizomatic-methodologies

Lakoff, G. (1993). The contemporary theory of metaphor. In A. Ortony (Ed.), Metaphor and thought (pp. 202-251). New York, NY: Cambridge University Press. 
Lakoff, G., \& Johnson, M. (1999). Philosophy in the flesh: The embodied mind and its challenge to Western thought. New York, NY: Basic Books.

Lakoff, G., \& Johnson, M. (2008). Metaphors we live by. Chicago, IL: University of Chicago Press.

Leung, G. (2010, September 16). Nomadic thinking [Blog post]. Critical Legal Thinking. Retrieved from http://criticallegalthinking.com/2010/09/16/nomadic-thinking/

Liyanagunawardena, T. R., Adams, A. A., \& Williams, S. A. (2013). MOOCs: A systematic study of the published literature 2008-2012. International Review of Research in Open and Distributed Learning, 14(3), 202-227. Retrieved from http://www.irrodl.org/index.php/irrodl/article/view/1455

Mackness, J. (2011, November 10). Rhizomatic learning - Does the metaphor stand up? [Blog post]. Jenny Connected. Retrieved from https://jennymackness.wordpress.com/2011/11/10/rhizomaticlearning-\%E2\%80\%93-does-the-metaphor-stand-up/

Mackness, J., \& Bell, F. (2015). Rhizo14: A rhizomatic learning cMOOC in sunlight and in shade. Open Praxis, 7(1), 25-38. Retrieved from http://openpraxis.org/index.php/OpenPraxis/article/view/173

Massumi, B. (1992). A user's guide to capitalism and schizophrenia: Deviations from Deleuze and Guattari. Cambridge: MIT Press.

Massumi, B. (Trans.). (2013). Notes on the translation and acknowledgements. A thousand plateaus: Capitalism and schizophrenia (pp. vii -xviii). Minneapolis: University of Minnesota Press.

Morgan, G. (1997). Images of organization. London: Sage.

Munday, I. (2012). Roots and rhizomes - Some reflections on contemporary pedagogy. Journal of Philosophy of Education, 46(1), 42-59. doi:10.1111/j.1467-9752.2011.00825.x

Northcote, M., \& Fetherston, T. (2006). New metaphors for teaching and learning in a university context. In Critical Visions, Proceedings of the 29th HERDSA Annual Conference (pp. 251-258). Milperra: Higher Education Research and Development Society of Australasia. Retrieved from http://www.herdsa.org.au/wp-content/uploads/conference/2006/papers/Northcote.pdf

Reddy, M. J. (1979). The conduit metaphor: A case of frame conflict in our language about language. In A. Ortony (Ed.), Metaphor and thought (1st ed., pp. 164-201). Cambridge: Cambridge University Press.

St. Pierre, E. (1997). Nomadic inquiry in the smooth spaces of the field: A preface. International Journal of Qualitative Studies in Education, 10(3), 365-383. doi:10.1080/095183997237179

St. Pierre, E. A. (2004). Deleuzian concepts for education: The subject undone. Educational Philosophy and Theory, 36(3), 283-296. doi:10.1111/j.1469-5812.2004.00068.x

Winslade, J. (2009). Tracing lines of flight: Implications of the work of Gilles Deleuze for narrative practice. Family Process, 48(3), 332-346. doi:10.1111/j.1545-5300.2009.01286.x

Wray, S. (1998). Rhizomatic-nomadic resistant Internet use. Retrieved from http://www.thing.net/ rdom/ecd/rhizomatic.html\#RESISTANT

Yousef, A. M. F., Chatti, M. A., Schroeder, M.W., \& Jakobs, H. (2014). A review of the state-of-the-art. In Proceedings of CSEDU2014, 6th International Conference on Computer Supported Education (pp. 9-20). Retrieved from http://www.openeducationeuropa.eu/en/article/MOOCs---A-Review-of-theState-of-the-Art

Yuan, B. L., \& Powell, S. (2013). MOOCs and open education: Implications for higher education (A White Paper). JISC CETIS. Retrieved from http://publications.cetis.ac.uk/2013/667

Corresponding author: Jenny Mackness, jenny.mackness@btopenworld.com

Australasian Journal of Educational Technology (c) 2016.

Please cite as: Mackness, J., Bell. F., \& Funes, M. (2016). The rhizome: A problematic metaphor for teaching and learning in a MOOC. Australasian Journal of Educational Technology, 32(1), 78-91. 